\title{
IMPLIKASI UNDANG-UNDANG NOMOR 14 TAHUN 2008 TENTANG KETERBUKAAN INFORMASI PUBLIK PADA INFORMASI TEKNOLOGI PENGELOLAAN AIR BERSIH DAN LIMBAH CAIR
}

\author{
Oleh: Komarudin dan Heru Dwi Wahjono \\ Badan Pengkajian dan Penerapan Teknologi
}

\begin{abstract}
Since the Internet was introduced virtual network, the globalization of information gradually changes. One positive result of the globalization of this information is the geographical boundaries are not visible in the face of the earth. Information wide open to anyone who would like to access and contribute in it. To protect the rights and obligations of both the information providers and the users from the cyber crime, the government has prepared several law and legislation. On this paper, the regulation of public information opennes (Law Number 14/2008) will be discussed, which protect the rights of people to access information held by public agencies and institutions. Example given is associated with the provision of information for environmental problems, particularly water management technology and liquid waste that has been managed by the Center for Environmental Technology, Agency for the Assessment and Application of Technology.
\end{abstract}

Keywords : Keterbukaan Informasi Publik, Pelayanan Informasi Teknologi, Hak Akses, Jaringan Global Internet, Hubungan Masyarakat, Cyber Crime, dan Good Gevernance

\section{PENDAHULUAN}

\subsection{Latar Belakang}

Keterbukaan Informasi Publik (KIP) merupakan perwujudan hak asasi manusia dan tata pemerintahan yang baik (good governance), meliputi tata kelola pemerintahan yang baik (good public governance) dan tata kelola perusahaan yang baik (good corporate governance), partisipasi masyarakat, pelayanan publik yang berkualitas, serta pengelolaan sumber daya alam berbasis daya dukung ekosistem dan kepentingan masyarakat ${ }^{1)}$.

Ruang lingkup hak atas informasi meliputi Hak Untuk Mengetahui (Right to Know), Hak untuk Menghadiri Pertemuan Publik (Right to Observe/Right to Attend Public Meeting), Hak Untuk Mendapatkan Salinan Informasi (Right to Obtain the Copy/Akses Pasif), Hak Untuk Diinformasikan tanpa Harus Ada Permintaan (Right to be Informed/Akses Aktif), dan Hak Untuk Menyebarluaskan Informasi (Right to Disseminate) 9). Eksistensi regulasi mengenai keterbukaan informasi publik dapat mendorong masyarakat menjadi lebih demokratis dengan memungkinkan adanya akses masyarakat terhadap informasi yang dimiliki pemerintah baik pemerintah pusat, pemerintah daerah maupun lembaga-lembaga publik lain seperti lembaga pendidikan dan lembaga kesehatan, misalnya rumah sakit.

UU KIP merupakan salah satu wujud konkrit demokratisasi di Indonesia dan salah satu pilar good governance, merupakan Inisiatif DPR, salah satu Undang-Undang yang menjadi perhatian "publik" (di samping UU Tentang Informasi dan Transaksi Elektronik, UU Tentang Penyiaran, UU Tentang Ombudsman, dan RUU tentang Pelayanan Publik), mengacu pada Pasal $28 \mathrm{~F}$ jo. $28 \mathrm{~J}$ UUD 1945, mengubah pola pikir dalam berbagai sektor publik karena mengandung prinsip-prinsip baru yang sebelumnya tidak diterapkan, regulasi yang sangat mempengaruhi transparansi, good governance dan demokratisasi. Penting dicatat, perlu harmonisasi UU KIP dengan UU terkait. Undang Undang Dasar Negara Republik Indonesia 1945, Pasal 28F berbunyi: "setiap orang berhak untuk berkomunikasi dan memperoleh informasi untuk mengembangkan pribadi dan lingkungan sosialnya, serta berhak untuk mencari, memperoleh, memiliki, dan menyimpan informasi dengan menggunakan segala jenis saluran yang tersedia." Untuk memberikan jaminan terhadap semua orang dalam memperoleh informasi, perlu dibentuk Undang-Undang yang mengatur tentang Keterbukaan Informasi Publik.

Salah satu elemen penting dalam mewujudkan penyelenggaraan pemerintahan yang terbuka adalah hak untuk memperoleh informasi sesuai dengan peraturan perundangundangan. Hak atas informasi menjadi sangat penting, karena makin terbuka penyelenggaraan negara untuk diawasi publik, penyelenggaraan negara tersebut makin dapat dipertanggung jawabkan. Hak setiap orang untuk memperoleh informasi juga relevan untuk meningkatkan 
kualitas pelibatan masyarakat dalam proses pengambilan keputusan publik. Partisipasi atau pelibatan masyarakat tidak banyak berarti tanpa jaminan Keterbukaan Informasi Publik.

Keberadaan Undang-Undang tentang Keterbukaan linformasi Publik sangat penting sebagai landasan hukum yang berkaitan dengan (1) Hak setiap orang untuk memperoleh informasi; (2) Kewajiban badan publik menyediakan dan melayani permintaan informasi secara cepat, tepat waktu, biaya ringan/proporsional, dan cara sederhana; (3) Pengecualian bersifat ketat dan terbatas; dan (4) Kewajiban badan publik untuk membenahi sistem dokumentasi dan pelayanan informasi.

Setiap Badan Publik mempunyai kewajiban untuk membuka akses atas Informasi Publik yang berkaitan dengan Badan Publik tersebut untuk masyarakat luas. Lingkup Badan Publik dalam Undang-Undang ini meliputi lembaga eksekutif, legislatif, yudikatif, serta penyelenggara negara lainnya yang mendapatkan dana dari APBN/APBD dan mencakup pula organisasi non pemerintah, baik yang berbadan hukum maupun yang tidak berbadan hukum, seperti lembaga swadaya masyarakat, perkumpulan, serta organisasi lainnya yang mengelola atau menggunakan dana yang sebagian atau seluruhnya bersumber dari APBN/APBD, sumbangan masyarakat, dan/atau luar negeri.

Melalui mekanisme dan pelaksanaan
prinsip keterbukaan, akan tercipta
kepemerintahan yang baik dan peran serta
masyarakat yang transparan dan akuntabilitas
yang tinggi sebagai salah satu prasyarat untuk
mewujudkan demokrasi yang hakiki. Dengan
membuka akses publik terhadap informasi
diharapkan Badan Publik termotivasi untuk
bertanggungjawab dan berorientasi pada
pelayanan rakyat yang sebaik-baiknya. Dengan
demikian, hal itu dapat mempercepat perwujudan
pemerintahan yang terbuka yang merupakan
upaya strategis mencegah praktik korupi, kolusi,
dan nepotisme (KKN) dan terciptanya
kepemerintahan yang baik (good governance).

\subsection{Tujuan dan Sasaran}

Penulisan artikel ini bertujuan untuk memberikan penjelasan tentang salah satu regulasi pemerintah yakni mengenai keterbukaan informasi publik, khususnya penerapannya dalam penyebarluasan informasi teknologi pengelolaan air bersih dan limbah cair. Adapun sasarannya adalah memberikan informasi kepada masyarakat mengenai hak-haknya dalam memperoleh informasi yang berasal dari institusi pemerintah khususnya dikaitkan dengan informasi teknologi lingkungan bidang pengelolaan air bersih dan limbah cair.

\section{UNDANG-UNDANG TENTANG KETERBUKAAN INFORMASI PUBLIK}

\subsection{Informasi Umum UU Tentang KIP}

UU Tentang KIP berisi empat belas bab, yaitu ketentuan umum, asas dan tujuan, hak dan kewajiban pemohon dan pengguna informasi publik serta hak dan kewajiban badan publik, informasi yang wajib disediakan dan diumumkan, informasi yang dikecualikan, mekanisme memperoleh informasi, komisi informasi, keberatan dan penyelesaian sengketa melalui Komisi Informasi, hukum acara komisi, gugatan ke pengadilan dan kasasi, ketentuan pidana, ketentuan lain-lain, ketentuan peralihan, dan ketentuan penutup.

Informasi publik adalah informasi yang dihasilkan, disimpan, dikelola, dikirim, dan/atau diterima oleh suatu Badan Publik yang berkaitan dengan penyelenggara dan penyeleng-garaan negara dan/atau penyelenggara dan penyelenggaraan Badan Publik lainnya yang sesuai dengan Undang-Undang ini serta informasi lain yang berkaitan dengan kepentingan publik. Badan publik adalah lembaga eksekutif, legislatif, yudikatif, dan badan lain yang fungsi dan tugas pokoknya berkaitan dengan penyelenggaraan negara yang sebagian atau seluruh dananya bersumber dari anggaran pendapatan dan belanja negara (APBN) dan/atau anggaran pendapatan dan belanja daerah (APBD) atau organisasi nonpemerintah sepanjang sebagian atau seluruh dananya bersumber dari APBN dan/atau APBD, sumbangan masyarakat, dan/atau luar negeri.

Landasan UU KIP adalah Pasal 20, Pasal 21, Pasal 28F, dan Pasal 28J UUD NRI 1945. UU KIP didasarkan atas pertimbangan informasi merupakan kebutuhan pokok setiap orang, hak memperoleh informasi merupakan HAM dan KIP merupakan ciri demokratisasi, KIP merupakan sarana dalam meningkatkan pelayanan publik dan melakukan pengawasan publik, dan pengelolaan informasi publik yang baik merupakan upaya menumbuhkembangkan masyarakat informasi. Beberapa catatan penting dari undang-undang ini, antara lain:

a. Ditetapkan 30 April 2008, merupakan prestasi bangsa dalam mewujudkan demokrasi dan tata pemerintahan yang baik. 
b. KIP mempunyai makna yang luas: Badan Publik (eksekutif, legislatif, yudikatif) harus mempertanggungjawabkan kepada masyarakat, menyampaikan informasi secara terbuka.

c. Siapa pun yang melaksanakan tugas dan fungsi menggunakan dana, sebagian atau seluruh dana dari APBN/APBD dan sumbangan dana publik, harus menyampaikan informasi secara terbuka kepada masyarakat.

d. Namun ada informasi yang dikecualikan, tidak bisa disampaikan kepada masyarakat, antara lain informasi strategis dan rahasia bisnis, informasi rahasia negara, informasi intelijen dan sandi negara, dan informasi yang bersifat pribadi.

e. KIP seharusnya dapat mengubah secara mendasar kehidupan bermasyarakat, berbangsa, dan bernegara.

f. Perlu kesadaran bangsa, agar dalam pengelolaan informasi publik, dilakukan dengan prinsip-prinsip good governance.

g. Membuka informasi merupakan kewajiban seluruh elemen bangsa.

h. UU KIP dilaksanakan mulai 30 April 2010, dua tahun setelah diundangkan.

\subsection{Isi UU Tentang KIP}

Ada dua belas pengertian dalam UU KIP yang harus dicermati, yaitu informasi, informasi publik, badan publik, komisi informasi, sengketa informasi publik, mediasi, ajudikasi, pejabat publik, pejabat pengelola informasi dan dokumentasi, orang, pengguna informasi publik, dan pemohon informasi publik. Bab I adalah Ketentuan Umum. Bab II berisi Asas dan Tujuan. Asas meliputi (a) Setiap Informasi Publik bersifat terbuka dan dapat diakses dan Informasi Publik yang dikecualikan bersifat ketat dan terbatas (maximum access limited exemption); dan (b) Informasi Publik harus dapat diperoleh secara cepat dan tepat waktu, biaya ringan, dan cara sederhana. Tujuan undang-undang ini, (a) menjamin hak warga negara untuk mengetahui segala sesuatu yang berkaitan dengan kebijakan publik; (b) mendorong partisipasi masyarakat; (c) meningkatkan peran aktif masyarakat; (d) mewujudkan penyelenggaraan negara yang baik; (e) mengembangkan ilmu pengetahuan dan mencerdaskan kehidupan bangsa; dan (f) meningkatkan pengelolaan dan pelayanan informasi di lingkungan Badan Publik.

Bab III adalah Hak dan Kewajiban Pemohon dan Pengguna Informasi Publik dan Hak dan Kewajiban Badan Publik. Hak pemohon dan pengguna informasi publik meleiputi (1) memperoleh Informasi Publik sesuai dengan ketentuan Undang-Undang ini; (2) melihat dan mengetahui Informasi Publik; (3) menghadiri pertemuan publik yang terbuka untuk umum untuk memperoleh Informasi Publik; (4) mendapatkan salinan Informasi Publik melalui permohonan sesuai dengan UU ini; (5) menyebarluaskan Informasi Publik sesuai dengan peraturan perundang-undangan; (6) mengajukan permintaan Informasi Publik disertai alasan permintaan tersebut; dan / atau (7) mengajukan gugatan ke pengadilan apabila dalam memperoleh Informasi Publik mendapat hambatan atau kegagalan sesuai dengan ketentuan Undang-Undang ini. Kewajiban pemohon dan pengguna informasi publik adalah (1) menggunakan Informasi Publik sesuai dengan ketentuan peraturan perundangundangan; dan (2) mencantumkan sumber dari mana ia memperoleh Informasi Publik, baik yang digunakan untuk kepentingan sendiri maupun untuk keperluan publikasi sesuai dengan ketentuan peraturan perundang-undangan.

Hak Badan Publik meliputi (1) menolak memberikan informasi yang dikecualikan sesuai dengan ketentuan peraturan perundangundangan; dan (2) menolak memberikan Informasi Publik apabila tidak sesuai dengan ketentuan peraturan perundang-undangan. Kewajiban Badan Publik meliputi (1) menyediakan, memberikan dan/atau menerbitkan Informasi Publik yang berada di bawah kewenangannya kepada Pemohon Informasi Publik, selain informasi yang dikecualikan sesuai dengan ketentuan; (2) menyediakan Informasi Publik yang akurat, benar, dan tidak menyesatkan; (3) membangun dan mengembangkan sistem informasi dan dokumentasi untuk mengelola Informasi Publik secara baik dan efisien sehingga dapat diakses dengan mudah; dan (4) membuat pertimbangan secara tertulis setiap kebijakan yang diambil untuk memenuhi hak setiap Orang atas Informasi Publik.

Bab IV berisi Informasi yang Wajib Disediakan dan Diumumkan. Terdapat enam jenis informasi publik yang dapat diakses, yaitu (1) Informasi Yang Wajib Disediakan Dan Diumumkan Secara Berkala; (2) Informasi Yang Wajib Diumumkan Secara Serta Merta; (3) Informasi Yang Wajib Tersedia Setiap Saat; (4) Informasi Publik yang wajib disediakan oleh BUMN, BUMD dan/atau badan usaha lainnya yang dimiliki oleh negara; (5) Informasi Publik yang wajib disediakan oleh partai politik; dan (6) Informasi Publik yang wajib disediakan oleh organisasi nonpemerintah. 
Informasi yang Wajib Disediakan dan Diumumkan Secara Berkala meliputi (a) informasi yang berkaitan dengan badan publik; (b) informasi mengenai kegiatan dan kinerja badan publik terkait; (c) informasi mengenai laporan keuangan; dan (d) informasi lain yang diatur dalam peraturan perundang-undangan. Informasi yang Wajib Diumumkan Secara Serta Merta adalah Informasi yang dapat mengancam hajat hidup orang banyak dan ketertiban umum.

Informasi yang Wajib Tersedia Setiap Saat meliputi (a) daftar seluruh informasi publik yang berada di bawah penguasaannya, tidak termasuk informasi yang dikecualikan; (b) hasil keputusan badan publik dan pertimbangannya; (c) seluruh kebijakan yang ada berikut dokumen pendukungnya; (d) rencana kerja proyek termasuk di dalamnya perkiraan pengeluaran tahunan badan publik; (e) perjanjian badan publik dengan pihak ketiga; (f) informasi dan kebijakan yang disampaikan pejabat publik dalam pertemuan yang terbuka untuk umum; (g) prosedur kerja pegawai badan publik yang berkaitan dengan pelayanan masyarakat; dan (h) laporan mengenai pelayanan akses informasi publik sebagaimana diatur dalam UndangUndang ini.

Juga diatur tentang informasi publik yang wajib disediakan oleh BUMN/BUMD dan/atau badan usaha lainnya yang dimiliki oleh negara. Informasi yang dimaksud meliputi (a) nama dan tempat kedudukan, maksud dan tujuan serta jenis kegiatan usaha, jangka waktu pendirian, dan permodalan, sebagaimana tercantum dalam Anggaran Dasar; (b) nama lengkap pemegang saham, anggota Direksi, dan anggota Dewan Komisaris Perseroan; (c) laporan tahunan, laporan keuangan, neraca laporan laba rugi, dan laporan tanggung jawab sosial perusahaan yang telah diaudit; (d) hasil penilaian oleh eksternal auditor, lembaga pemeringkat kredit dan lembaga pemeringkat lainnya; (e) sistem dan alokasi dana remunerasi anggota komisaris / dewan pengawas dan direksi; (f) mekanisme penetapan direksi dan komisaris / dewan pengawas; (g) kasus hukum yang berdasarkan undang-undang terbuka sebagai informasi publik; (h) pedoman pelaksanaan tata kelola perusahaan yang baik berdasarkan prinsipprinsip transparansi, akuntabilitas, pertanggungjawaban, kemandirian, dan kewajaran; (i) pengumuman penerbitan efek yang bersifat utang; (j) penggantian akuntan yang mengaudit perusahaan; (k) perubahan tahun fiskal perusahaan; (I) kegiatan penugasan pemerintah dan/atau kewajiban pelayanan umum atau subsidi; $(\mathrm{m})$ mekanisme pengadaan barang dan jasa; dan (n) informasi lain yang ditentukan oleh Undang-Undang yang berkaitan dengan Badan Usaha Milik Negara/Badan Usaha Milik Daerah.

Informasi Publik yang wajib disediakan oleh Partai Politik meliputi asas dan tujuan; program umum dan kegiatan Partai Politik; nama alamat dan susunan kepengurusan dan perubahannya; pengelolaan dan penggunaan dana yang bersumber dari Anggaran Pendapatan dan Belanja Negara dan/atau Anggaran Pendapatan dan Belanja Daerah; mekanisme pengambilan keputusan partai; keputusan partai: muktamar/kongres/munas/dan keputusan lainnya yang menurut Anggaran Dasar dan Anggaran Rumah Tangga partai terbuka untuk umum; dan informasi lain yang ditetapkan oleh UndangUndang yang berkaitan dengan Partai Politik.

Informasi Publik pada Organisasi Non Pemerintah meliputi asas dan tujuan; program dan kegiatan organisasi; nama, alamat, susunan kepengurusan, dan perubahannya; pengelolaan dan penggunaan dana yang bersumber dari Anggaran Pendapatan dan Belanja Negara dan/atau Anggaran Pendapatan dan Belanja Daerah, sumbangan masyarakat, dan/atau sumber luar negeri; mekanisme pengambilan keputusan organisasi; keputusan-keputusan organisasi; dan informasi lain yang ditetapkan oleh peraturan perundang-undangan.

Bab $V$ berisi Informasi yang Dikecualikan. Ketentuan tentang informasi yang dikecualikan meliputi (a) Informasi yang apabila dibuka dapat menghambat proses penegakan hukum; (b) Informasi yang apabila dibuka dapat mengganggu kepentingan perlindungan hak atas kekayaan intelektual dan perlindungan dari persaingan usaha tidak sehat; (c) Informasi yang apabila dibuka dapat membahayakan pertahanan negara dan keamanan negara; (d) Informasi yang apabila dibuka dapat mengungkapkan kekayaan alam Indonesia; (e) Informasi yang apabila dibuka dapat merugikan ketahanan ekonomi nasional; (f) informasi yang apabila dibuka dapat merugikan kepentingan hubungan luar negeri; (g) Informasi yang apabila dibuka dapat mengungkapkan isi akta otentik yang bersifat pribadi dan kemauan terakhir ataupun wasiat seseorang; (h) Informasi yang apabila dibuka dapat mengungkap rahasia pribadi; (i) Memorandum atau surat-surat antar badan publik atau intra badan publik, yang menurut sifatnya dirahasiakan kecuali atas putusan Komisi Informasi atau pengadilan; (j) Informasi yang tidak boleh diungkapkan berdasarkan UndangUndang; (k) Informasi yang dikecualikan tidak bersifat permanen; dan (I) Ketentuan lebih lanjut 
mengenai jangka waktu pengecualian diatur dengan Peraturan Pemerintah.

Bab VI mengatur tentang Mekanisme Memperoleh Informasi, yaitu (a) Pemerolehan Informasi Publik didasarkan pada prinsip cepat, tepat waktu, dan biaya ringan; (b) Setiap Pemohon Informasi Publik dapat mengajukan permintaan untuk memperoleh Informasi Publik kepada Badan Publik secara tertulis atau tidak tertulis; dan (c) Badan Publik yang bersangkutan wajib menyampaikan pemberitahuan terkait informasi publik yang diminta paling lambat 10 hari kerja

Bab VII mengatur Komisi Informasi. Komisi Informasi adalah lembaga mandiri yang berfungsi menjalankan Undang-Undang ini dan peraturan pelaksanaannya menetapkan petunjuk teknis standar layanan Informasi Publik dan menyelesaikan Sengketa Informasi Publik melalui Mediasi dan/atau Ajudikasi nonlitigasi. Komisi Informasi terdiri atas: 1) Komisi Informasi Pusat; 2) Komisi Informasi Provinsi; dan 3) Komisi Informasi Kabupaten/Kota (jika dibutuhkan). Anggota Komisi Informasi Pusat berjumlah 7 (tujuh) orang yang mencerminkan unsur pemerintah dan unsur masyarakat. Anggota Komisi Informasi Provinsi dan/atau Kabupaten/Kota berjumlah 5 (lima) orang yang mencerminkan unsur pemerintah dan unsur masyarakat. Calon anggota Komisi Informasi diajukan oleh Presiden/Gubernur untuk diuji kepatutan dan kelayakan oleh DPR/DPRD. Penetapan anggota Komisi Informasi dilakukan oleh Presiden/Gubernur/Walikota/Bupati.

Bab VIII berisi Keberatan dan Penyelesaian Sengketa Melalui Komisi Informasi. Setiap Pemohon Informasi Publik dapat mengajukan keberatan secara tertulis kepada atasan Pejabat Pengelola Informasi dan Dokumentasi apabila tidak dipenuhinya permintaan atas informasi publik. Apabila setelah mengajukan keberatan kepada atasan Pejabat Pengelola Informasi dan Dokumentasi belum mendapatkan jawaban yang memuaskan, pemohon informasi publik dapat melakukan upaya penyelesaian sengketa informasi publik yang diajukan kepada Komisi Informasi.

Bab IX mengatur Hukum Acara Komisi. Penyelesaian sengketa informasi publik oleh Komisi Informasi dilakukan melalui proses: a) Mediasi; dan b) Ajudikasi nonlitigasi. Dalam proses Mediasi anggota Komisi Informasi berperan sebagai mediator. Penyelesaian Sengketa Informasi Publik melalui Ajudikasi nonlitigasi hanya dapat ditempuh apabila upaya Mediasi dinyatakan tidak berhasil. Putusan
Komisi Informasi yang berasal dari kesepakatan melalui Mediasi bersifat final dan mengikat. Putusan Komisi Informasi yang berasal dari proses Ajudikasi non litigasi, masih dapat dilanjutkan dengan Pengajuan gugatan ke Pengadilan. Sidang Komisi Informasi bersifat tertutup apabila pemeriksaan berkaitan dengan dokumen-dokumen yang termasuk dalam pengecualian. Putusan Komisi Informasi adalah membatalkan putusan atasan Badan Publik dan memutuskan untuk memberikan sebagian atau seluruh informasi yang diminta oleh Pemohon Informasi Publik sesuai dengan keputusan Komisi Informasi; atau mengukuhkan putusan atasan Pejabat Pengelola Informasi dan Dokumentasi untuk tidak memberikan informasi yang diminta sebagian atau seluruhnya.

BAB X berupa Gugatan ke Pengadilan dan Kasasi. Pengajuan gugatan dilakukan melalui pengadilan tata usaha negara apabila yang digugat adalah Badan Publik negara. Pengajuan gugatan dilakukan melalui pengadilan negeri apabila yang digugat adalah Badan Publik selain Badan Publik negara. Pihak yang tidak menerima putusan Pengadilan Tata Usaha Negara/Pengadilan Negeri dapat mengajukan kasasi kepada Mahkamah Agung selambatlambatnya dalam waktu 14 (empat belas) hari sejak diterimanya putusan Pengadilan Tata Usaha Negara/Pengadilan Negeri.

BAB XI mengatur Ketentuan Pidana. Setiap Orang yang dengan sengaja menggunakan Informasi Publik secara melawan hukum dipidana dengan pidana penjara paling lama 1 (satu) tahun dan/atau pidana denda paling banyak Rp 5.000.000,00 (lima juta rupiah). Badan Publik yang dengan sengaja tidak menyediakan, tidak memberikan, dan/atau tidak menerbitkan Informasi Publik berupa Informasi Publik secara berkala, Informasi Publik yang wajib diumumkan secara serta-merta, Informasi Publik yang wajib tersedia setiap saat, dan/atau Informasi Publik yang harus diberikan atas dasar permintaan sesuai dengan Undang-Undang ini, dan mengakibatkan kerugian bagi Orang lain dikenakan pidana kurungan paling lama 1 (satu) tahun dan/atau pidana denda paling banyak $\mathrm{Rp}$ $5.000 .000,00$ (lima juta rupiah).

Setiap Orang yang dengan sengaja dan melawan hukum menghancurkan, merusak, dan/atau menghilangkan dokumen Informasi Publik dalam bentuk media apa pun yang dilindungi negara dan/atau yang berkaitan dengan kepentingan umum dipidana dengan pidana penjara paling lama 2 (dua) tahun dan/atau pidana denda paling banyak Rp 10.000.000,00 (sepuluh juta rupiah). Setiap 
Orang yang dengan sengaja dan tanpa hak mengakses dan/atau memperoleh dan/atau memberikan informasi yang dikecualikan dipidana dengan pidana penjara paling lama 2 (dua) tahun dan pidana denda paling banyak $\mathrm{Rp}$ 10.000.000,00 (sepuluh juta rupiah). Apabila menyangkut informasi yang menyangkut pertahanan negara, dipidana dengan pidana penjara paling lama 3 (tiga) tahun dan pidana denda paling banyak Rp 20.000.000,00 (dua puluh juta rupiah). Setiap Orang yang dengan sengaja membuat Informasi Publik yang tidak benar atau menyesatkan dan mengakibatkan kerugian bagi Orang lain dipidana dengan pidana penjara paling lama 1 (satu) tahun dan/atau denda paling banyak Rp 5.000.000,00 (lima juta rupiah).

BAB XII tentang Ketentuan Lain-lain menegaskan, Peraturan Pemerintah tentang tata cara pembayaran ganti rugi oleh Badan Publik negara diatur dengan peraturan pemerintah. BAB XIII tentang Ketentuan Peralihan. Komisi Informasi Pusat harus sudah dibentuk paling lambat 1 (satu) tahun sejak diundangkannya undang-undang ini. Komisi Informasi Provinsi harus sudah dibentuk paling lambat 2 (dua) tahun sejak diundangkannya undang-undang ini.

Pada saat diberlakukannya undangundang ini Badan Publik harus melaksanakan kewajibannya berdasarkan undang-undang. Peraturan Pemerintah sudah harus ditetapkan sejak diberlakukannya undang-undang ini. BAB XIV tentang Ketentuan Penutup menegaskan, (1) UU KIP berlaku 2 (dua) tahun sejak tanggal diundangkan; dan (2) Penyusunan dan penetapan Peraturan Pemerintah, petunjuk teknis, sosialisasi, sarana dan prasarana, serta hal-hal lainnya yang terkait dengan persiapan pelaksanaan Undang-Undang ini harus rampung paling lambat 2 (dua) tahun sejak UndangUndang ini diundangkan.

UU KIP mulai berlaku 2 (dua) tahun (30 April 2010) sejak tanggal diundangkan (30 April 2008). Dengan demikian penyusunan dan penetapan peraturan pemerintah, petunjuk teknis, sosialisasi, sarana dan prasarana, serta hal-hal lainnya yang terkait dengan persiapan pelaksanaan undang-undang ini harus rampung paling lambat 2 (dua) tahun sejak undangundang ini diundangkan, 30 April 2008.

\subsection{Pemahaman UU Tentang KIP}

Untuk memahami UU KIP, perlu dicermati penjelasan tentang hal-hal yang diatur, antara lain tepat waktu, cara sederhana, biaya ringan, konsekuensi yang timbul, membahayakan negara, persaingan usaha tidak sehat, rahasia jabatan, dan informasi publik yang diminta belum dikuasai atau didokumentasikan. Juga pengertian tentang berkala, informasi yang berkaitan dengan badan publik, kinerja badan publik, dan serta merta (spontan pada saat itu juga). Perlu dipahami juga pengertian tentang transparansi, kemandirian, akuntabilitas, pertanggungjawaban, dan kewajaran. Untuk mengetahui undangundang yang terkait dengan BUMN/BUMD adalah UU 19/2003 tentang BUMN dan UU 40/2007 tentang Perseroan Terbatas, sedangkan undang-undang yang berkaitan dengan partai politik adalah UU 22/2007 tentang Penyelenggara Pemilu, UU 2/2008 tentang Parpol, UU 10/2008 tentang Pemilu DPR, DPD, dan DPRD, serta UU tentang Susduk dan UU Piplres dan Pilwapres.

Harus dipahami organisasi non pemerintah, yaitu organisasi (berbadan hukum/tidak berbadan hukum) yang meliputi perkumpulan, lembaga swadaya masyarakat, badan usaha nonpemerintah yang sebagian atau seluruh dananya bersumber dari APBN/APBD, sumbangan masyarakat, dan/atau luar negeri. Juga harus dipahami Informasi yang terkait dengan sistem pertahanan dan keamanan negara/Dephan (infrastruktur pertahanan, gelar operasi militer, dan sistem persenjataan), Informasi yang terkait dengan sistem persandian negara/Lemsaneg (berkaitan dengan pengamanan informasi rahasia negara), dan Informasi yang terkait dengan sistem intelijen negara/BIN (sistem intelijen agar lebih terarah, terkoordinasi efektif, efisien, sinergis agar hasil analisisnya akurat, cepat, obyektif, dan relevan).

Mediasi adalah penyelesaian Sengketa Informasi Publik antara para pihak melalui bantuan mediator Komisi Informasi. Ajudikasi adalah proses penyelesaian Sengketa Informasi Publik antara para pihak yang diputus oleh Komisi Informasi. Harus dipahami tentang Memorandum yang dirahasiakan/surat-surat rahasia (memorandum/surat tidak disediakan untuk pihak lain), mandiri (independen, adil, kepentingan umum, dan kepentingan NKRI), ajudikasi nonlitigasi (penyelesaian sengketa ajudikasi di luar pengadilan yang putusannya memiliki kekuatan setara dengan putusan pengadilan) dan prosedur pelaksanaan penyelesaian sengketa (prosedur beracara di bidang penyelesaian sengketa Informasi yang dilakukan oleh Komisi Informasi). Kode etik harus ditegakkan, yaitu pedoman perilaku yang mengikat setiap anggota Komisi Informasi, yang penetapannya dilakukan oleh Komisi Informasi Pusat. 


\subsection{Keterkaitan UU KIP dengan UU Ombudsman}

UU KIP terkait dengan RUU tentang Pelayanan Publik (ditargetkan dalam waktu dekat dapat diundangkan), yang mengatur tentang pelayanan publik, penyelenggara pelayanan publik, organisasi penyelenggara pelayanan publik, pelaksana pelayanan publik, standar pelayanan, maklumat pelayanan, dan sistem informasi pelayanan publik. UU KIP juga terkait dengan UU Nomor 37 Tahun 2008 Tentang Ombudsman RI. Ombudsman Republik Indonesia yang selanjutnya disebut Ombudsman adalah lembaga negara yang mempunyai kewenangan mengawasi penyelenggaraana pelayanan publik baik yang diselenggarakan oleh penyelenggara negara dan pemerintahan termasuk yang diselenggarakan oleh Badan Usaha Milik Negara, Badan Usaha Milik Daerah, dan Badan Hukum Milik Negara serta badan swasta atau perseorangan yang diberi tugas menyelenggarakan pelayanan publik tertentu yang sebagian atau seluruh dananya bersumber dari anggaran pendapatan dan belanja negara dan/atau anggaran pendapatan dan belanja daerah.

Ombusman bertujuan (a) mewujudkan negara hukum yang demokratis, adil, dan sejahtera; (b) mendorong penyelenggaraan negara dan pemerintahan yang efektif dan efisien, jujur, terbuka, bersih, serta bebas dari korupsi, kolusi, dan nepotisme; (c) meningkatkan mutu pelayanan negara di segala bidang agar setiap warga negara dan penduduk memperoleh keadilan, rasa aman, dan kesejahteraan yang semakin baik; (d) membantu menciptakan dan meningkatkan upaya untuk pemberantasan dan pencegahan praktik-praktik maladministrasi, diskriminasi, kolusi, korupsi, dan nepotisme; dan (e) meningkatkan budaya hukum nasional, kesadaran hukum masyarakat, dan supremasi hukum yang berintikan kebenaran serta keadilan. Ombudsman berfungsi mengawasi penyelenggaraan pelayanan publik yang diselenggarakan oleh Penyelenggara Negara dan pemerintahan baik di pusat maupun di daerah termasuk yang diselenggarakan oleh Badan Usaha Milik Negara, Badan Usaha Milik Daerah, dan Badan Hukum Milik Negara serta badan swasta atau perseorangan yang diberi tugas menyelenggarakan pelayanan publik tertentu.

\section{IMPLEMENTASI UU KIP DALAM KEHUMASAN DAN PENYEDIAAN INFORMASI TEKNOLOGI PENGELOLAAN AIR BERSIH DAN LIMBAH CAIR}

\subsection{Implementasi UU KIP Dalam Humas Pemerintahan}

Aplikasi Undang-Undang KIP, UndangUndang Pelayanan Publik, dan Undang-Undang Ombudsman RI serta Undang-Undang terkait lainnya dan peraturan perundang-undangan terkait dalam kegiatan humas pemerintahan dan penyediaan informasi teknologi lingkungan, khususnya teknologi pengelolaan air bersih dan limbah cair, diharapkan dengan nyata mendukung upaya perwujudan:

a. Tata kelola pemerintahan yang baik (good public governance) dalam rangka penyediaan informasi teknologi dengan karakteristik:

1. Kesetaraan (equity): memberi peluang yang sama bagi setiap anggota masyarakat untuk meningkatkan kesejahteraannya.

2. Pengawasan (supervision): meningkatkan upaya pengawasan terhadap penyelenggara pemerintahan dan pembangunan dengan mengusahakan ketertiban swasta dan masyarakat luas.

3. Penegakan hukum (law enforcement): mewujudkan adanya penegakan hukum yang adil bagi semua pihak tanpa pengecualian, menjunjung tinggi HAM dan memperhatikan nilai-nilai yang hidup dalam masyarakat.

4. Daya Tanggap (responsiveness): meningkatkan kepekaan para penyelenggara pemerintahan terhadap aspirasi masyarakat, tanpa kecuali.

5. Efisiensi dan Efektivitas (effectiveness and efficiency): menjamin terselenggaranya pelayanan kepada masyarakat dengan menggunakan sumber daya yang tersedia secara optimal dan bertanggungjawab.

6. Partisipasi (participation): mendorong setiap warga untuk mempergunakan hak dalam menyampaikan pendapat dalam proses pengambilan keputusan, yang menyangkut kepentingan masyarakat, baik secara langsung maupun tidak langsung.

7. Profesionalisme (professionalism): meningkatkan kemampuan dan moral penyelenggara pemerintahan agar mampu memberi pelayanan yang mudah, cepat, dan tepat dengan biaya yang terjangkau.

8. Akuntabilitas

(accountability): meningkatkan tanggungjawab dan tanggunggugat para pengambil keputusan dalam segala bidang yang menyangkut kepentingan masyarakat luas. 
9. Wawasan ke Depan (strategic vision): membangun daerah berdasarkan visi dan strategi yang jelas dan mengikutsertakan warga dalam seluruh proses pembangunan, sehingga warga merasa memiliki dan ikut bertanggungjawab terhadap kemajuan daerahnya.

10. Transparansi (transparency): menciptakan kepercayaan timbal balik antara pemerintah dan masyarakat melalui penyediaan informasi dan menjamin kemudahan di dalam memperoleh informasi yang akurat dan memadai (Depdagri, UN-Habitat, APKASI, APEKSI, ADEKSI, 2003).

b. Tata kelola perusahaan yang baik (good corporate governance) dalam rangka penyediaan informasi teknologi, dengan unsur-unsur: "transparansi, akuntabilitas, responsibilitas, independen, dan kewajaran/ kesetaraan."

c. Tujuh asas pemerintahan yang bersih dan bebas KKN Undang-Undang Nomor 28 Tahun 1999): "kepastian hukum, tertib penyelenggaraan negara, kepentingan umum, keterbukaan, proporsionalitas, profesionalitas, dan akuntabilitas."

d. Mendukung pelaksanaan revitalisasi kehumasan pemerintah/humas pemerintahan: "baca: Kesepakatan Tiga Menteri: Mendagri, Menkominfo, dan Menpan tentang Revitalisasi Kehumasan, 2007."

e. Melaksanakan Etika Kehumasan: "Etika PNS (PP Nomor 42 Tahun 2004), Kode Etik, dan Budaya Kerja."

f. Melaksanakan Pedoman Umum Kehumasan Pemerintah/Humas Instansi Pemerintahan: "SDM, Kelembagaan, Profesionalitas, dan Sarana-Prasarana Humaspem."

Gambar berikut ini adalah salah satu contoh bentuk penyediaan informasi peraturan perundangan-undangan khususnya di bidang lingkungan sebagai berntuk tanggungjawab pemerintah kepada publik di bidang kebijakan.

\subsection{Implementasi Dalam Penyediaan Informasi Teknologi Pengelolaan Air Bersih dan Limbah Cair}

Masyarakat membutuhkan informasi publik yang terkait dengan teknologi lingkungan, khususnya teknologi pengolahan air bersih dan pengolahan air limbah, Sebaliknya humas pemerintah/unit kerja pengkajian teknologi berkewajiban menyediakan data/informasi yang dibutuhkan masyarakat dalam bentuk cetak maupun elektronik, antara lain terkait dengan masalah penyediaan informasi teknologi pengolaan air bersih dan limbah cair.

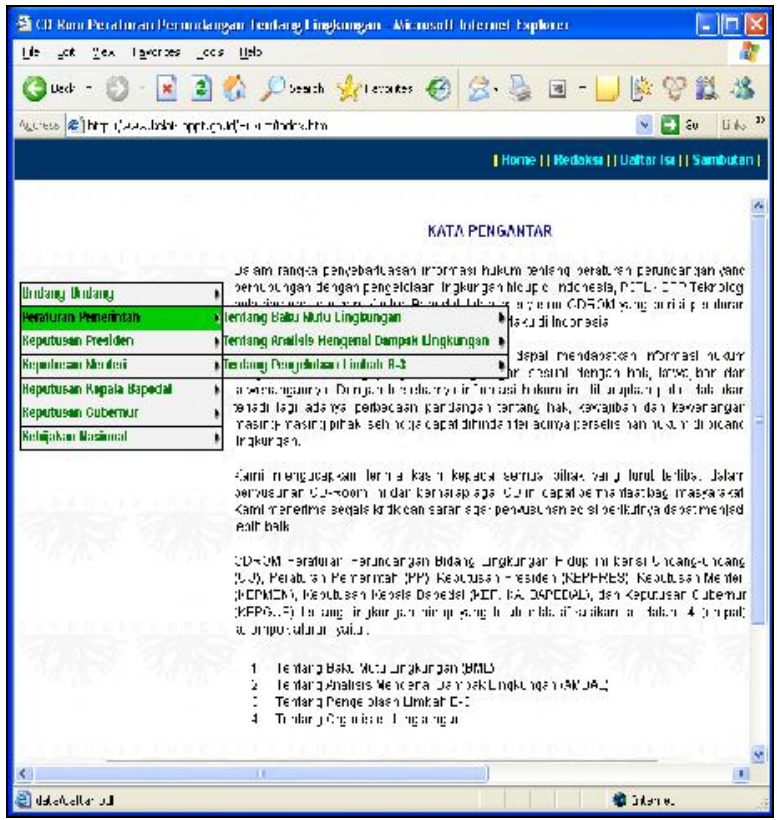

Gambar 1. Situs Peraturan PerundanganUndangan Bidang Lingkungan

Informasi tentang pencemaran air minum dan dampaknya terhadap kesehatan $\left.{ }^{6)}, 7\right)$, seperti penyakit yang berhubungan dengan air (waterborne diseases, antara lain disentri, typhus dan paratyphus, cholera, hepatitis $A$, penyakit yang berkaitan dengan kebersihan, dan mikroorganisme pathogen atau parasit di dalam air), bakteri pembentuk antibiotik, virus, parasit protozoa, bahaya oleh zat kimia yang ada dalam air minum, serta informasi tentang parameter kimia, parameter radioaktif, pengawasan kualitas air minum, air perpipaan, air kemasan, dan air kemasan isi ulang.

Informasi yang juga harus disediakan antara lain, polutan mikro di dalam air minum dan cara penanggulangannya, sumber pencemaran, air minum yang terkontaminasi, senyawa polutan yang bersifat racun, standar kualitas air minum, dan kontrol senyawa mikro polutan di dalam air minum. Masyarakat juga harus diinformasikan tentang kebijakan, strategi dan upaya penyediaan air bersih/air minum (PAM/PDAM, pengelolaan berbasis masyarakat, instalasi pengolahan air minum reverse osmosis (IPA$\mathrm{RO}$ ), dan penyediaan air bersih di desa nelayan). Informasi tentang fasilitas pengolahan air minum, meliputi karakteristik sumber air, perencanaan fasilitas penyediaan air bersih/air minum, fasilitas pengolahan air minum (sarana, prasarana, dan penggunaan zat-zat kimia). 
Pengolahan teknologi beberapa jenis air juga perlu diinformasikan, antara lain pengolahan air bersih dengan proses saringan pasir lambat up flow, pengolahan air sungai skala rumah tangga secara kontinu (karakteristik, parameter, koagulasi dan flokulasi, pengendapan, penyaringan, dan proses pengolahan), metoda praktis penghilangan zat besi dan mangan di dalam air minum, teknologi pengolahan air gambut sederhana, penghilangan kesadahan di dalam air minum, pengolahan air payau menjadi air minum dengan teknologi reverse osmosis, pengolahan air siap minum, disinfeksi untuk pengolahan air minum (disinfektan, mikroorganisme, senyawa khlor, ozon, dan sinar ultraviolet), dan daur ulang air limbah untuk air minum).

Informasi tentang pengelolaan air limbah, juga harus disediakan untuk masyarakat, meliputi sumber pencemaran dan polutan tercemar, kebijakan dan strategi pengelolaan air limbah domestik, teknologi pengolahan air limbah domestik, proses pengolahan air limbah dengan proses tertentu (biakan tersuspensi, film mikrobiologis/biofilm, trickling filter, reactor biologis putar, biofilter tercelup/aerob dan anaerob, penggunaan kolam (ponds), lagoon, dan pengolahan air limbah domestik individual atau semi komunal.

Beberapa contoh praktik di lapangan, misalnya pengelolaan air limbah domestik di DK Jakarta, perencanaan dan pembangunan IPAL Domestik kapasitas 150 M3 per hari, IPAL Domestik individual biofilter anaerobic, biofilter anaerob-aerob dengan media batu split, pelaksanaan AMDAL, Upaya Pengelolaan Lingkungan (UKL), Upaya Pemantauan Lingkungan (UPL), dan Izin Pembuangan Limbah Cair (IPLC), dan penegakan hukum lingkungan hidup secara terpadu. Gambar-gambar di samping ini adalah contoh bentuk pelayanan informasi kepada publik mengenai teknologi pengelolaan air bersih dan limbah cair.

\subsection{Implementasi Pada Penyediaan Informasi Data Sumber Daya Air}

Keterbukaan informasi kepada masyarakat mewajibkan institusi terkait memberikan informasi seluas-luasnya kepada masyarakat. Publik berhak mendapatkan informasi tidak hanya dalam bentuk cetak, namun dalam bentuk elektronik. Informasi data yang diberikan tidak hanya hasil olahan saja, namun raw data (data mentah) hasil survei suatu kajian pun berhak dimiliki oleh masyarakat. Salah satu implementasi keterbukaan informasi kepada publik adalah penyediaan informasi data sumber daya air. Melalui undang-undang no. 7 tahun 2004 tentang sumber daya air, data kualitas dan potensi sumber daya air nasional wajib dikelola oleh instansi terkait.

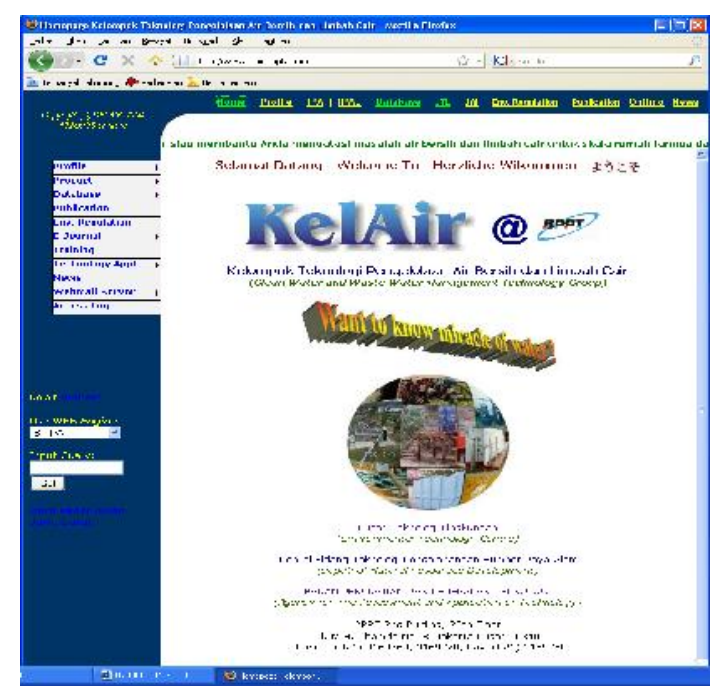

Gambar 2. Situs Informasi Teknologi Pengelolaan Air Bersih dan Limbah Cair

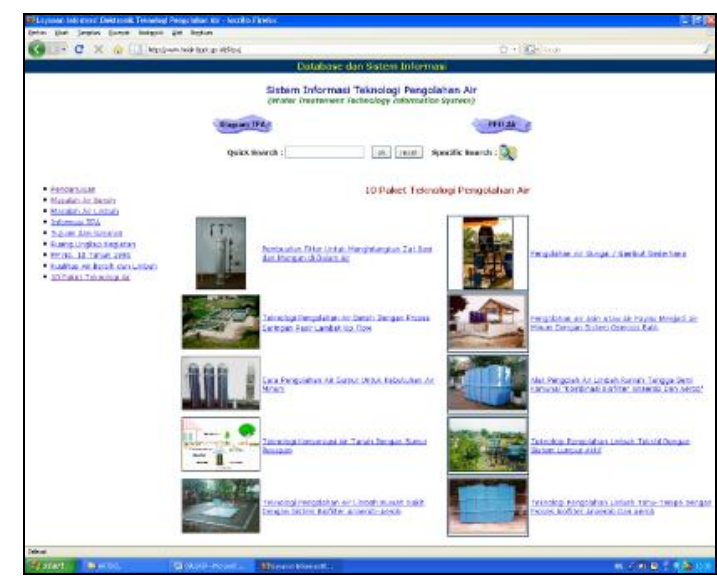

Gambar 3. Situs Paket Teknologi Pengolahan Air

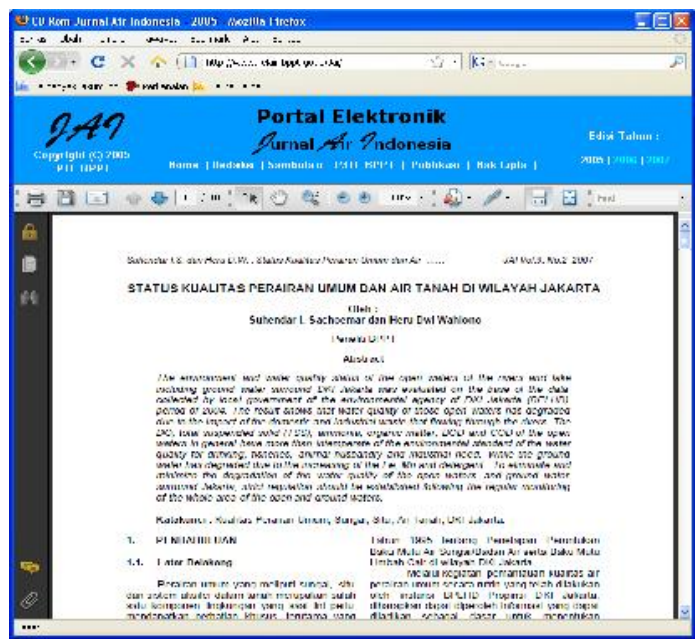

Gambar 4. Portal Elektronik Jurnal Air Indonesia 
Pemerintah baik pusat maupun daerah secara rutin, melalui instansi terkait telah melakukan bermacam-macam survei dan kegiatan untuk memantau kualitas dan potensi sumber daya air nasional. Setiap tahun telah diterbitkan laporan pemantuan tersebut. Untuk mempermudah publik dalam mengakses data mentah sumber daya air perlu disediakan database nasional yang menyediakan data kualitas dan potensi sumber daya air yang terdiri dari kumpulan informasi data dari setiap provinsi atau kabupaten/kota di Indonesia. Melalui pusat data ini diharapkan masyarakat dapat mengetahui kondisi kualitas dan potensi sumber daya air di wilayahnya, sehingga masyarakat dapat turut berpartisipasi dalam usaha pelestarian sumber daya air di wilayahnya yang sedang mengalami penurunan kualitas.

Berikut ini adalah contoh implementasi pada penyediaan informasi data sumber daya air.

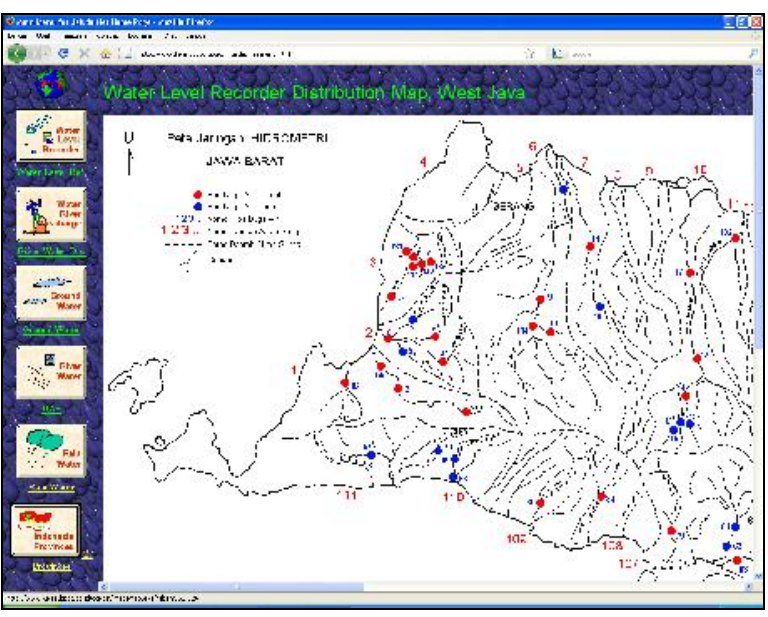

Gambar 5. Situs Informasi Pos Duga Air di Provinsi Jawa Barat

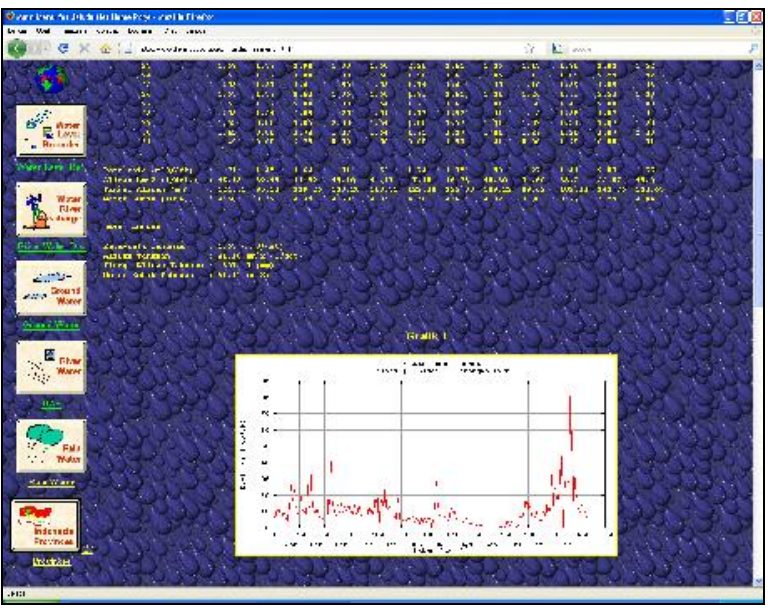

Gambar 6. Situs Informasi Data Sumberdaya Air Tentang Debit Sungai

\section{PENUTUP}

Undang-Undang tentang Keterbukaan Informasi Publik akan dilaksanakan pada April 2010, sehingga seluruh aparat pemerintah, dunia usaha/swasta, dan masyarakat perlu mempelajari dan memahami isi undang-undang ini. Humas pemerintahan dan badan publik lainnya harus menyediakan informasi dan memenuhi permintaan informasi dari masyarakat, sesuai dengan ketentuan undang-undang ini. Unit kehumasan instansi pemerintah dan swasta harus bekerjasama dengan unit-unit kerja di dalam instansi tersebut, agar penyediaan informasi berjalan lancar dan tepat waktu.

Setiap badan publik dan unit kerja pemerintahan harus menegakkan profesionalitas, netralitas, tidak diskriminatif, transparansi, akuntabilitas, etika dan kode etik, citra positif, obyektivitas, menyebarluaskan informasi dan menampung pendapat masyarakat, serta menegakkan prinsip-prinsip tata pemerintaha yang baik dalampenyediaan informasi publik.

Praktisi kehumasan pemerintah dan praktisi teknologi pengolahan air minum/air bersih, harus peka terhadap masalah-masalah aktual dan strategis, melakukan reorientasi, reposisi, dan revitalisasi, membangun jejaring (networking), menjadi fasilitator, melakukan perubahan paradigma, perubahan mind-set dan cultural-set serta sistem manajemen pemerintahan dalam penyediaan informasi publik, dan bekerja konsisten, sungguh-sungguh serius, lebih efisien, efektif, produktif, profesional, netral, motivatif, inovatif, kreatif, rasional, dan sejahtera.

\section{DAFTAR PUSTAKA}

1. Freddy H.Tolung, Depkominfo, "Sosialisasi UU 14/2008", Pertemuan Bakohumas seSumatera, Palembang, 26-27 Mei 2008.

2. Keputusan Menkominfo Nomor 371 Tahun 2007 Tentang Kode Etik Kehumasan Pemerintah (Humas Pemerintahan).

3. Kesepakatan Bersama Mendagri, Menkominfo, dan Menpan No. 41 Tahun 2007, Nomor 373/M.KOMINFO/08/2007, dan Nomor KB/01/M.PAN/08/2007 Tentang Revitalisasi Fungsi Hubungan Masyarakat Pada Instansi Pemerintah, Kesekretariatan Lembaga Negara, Pemerintah Daerah, dan Badan Usaha Milik Negara/Daerah.

4. Komarudin, Drs., M.A., APU, "UU KIP dan Implikasinya pada Kehumasan Pemerintah", Rapat Kerja Badan Kebijakan Publik, 
Departemen Kesehatan, Surabaya, 19-22 Oktober 2008.

5. Komarudin, Drs., M.A., APU, "Implementasi Pedoman Humas Pemerintah dan Pedoman Umum Humas Instansi Pemerintah", Makalah dipresentasikan pada Pertemuan Bakohumas se-Kawasan Barat Indonesia, Palembang, 26-27 Mei 2008.

6. Nusa Idaman Said, Ir., M.Eng., "Teknologi Pengolahan Air Minum: Teori dan Pengalaman Praktis", Pusat Teknologi Lingkungan, Badan Pengkajian dan Penerapan Teknologi, 2008.

7. Nusa Idaman Said, Ir., M.Eng., "Pengelolaan Air Limbah Domestik di DKI Jakarta: Tinjauan Permasalahan, Strategi dan Teknologi Pengolahan", Pusat Teknologi Lingkungan, Badan Pengkajian dan Penerapan Teknologi, 2008.
8. Permenpan Nomor PER/12/M.PAN/08/Tahun 2007 tentang Pedoman Umum Humas di lingkungan Instansi Pemerintah.

9. Suprawoto, Kepala Badan Informasi Publik, Depkominfo, "Sosialisasi UU 14/2008 tentang KIP di KPK", Maret 2008.

10. Undang-Undang Republik Indonesia Nomor 11 Tahun 2008 Tentang Informasi dan Transaksi Elektronik.

11. Undang-Undang Republik Indonesia Nomor 14 Tahun 2008 Tentang Keterbukaan Informasi Publik.

12. Undang-Undang Republik Indonesia Nomor 37 Tahun 2008 tentang Ombudsman Republik Indonesia. 
Sejak jaringan maya internet diperkenalkan, globalisasi informasi sedikit demi sedikit mengalami perubahan. Salah satu akibat positif dari globalisasi informasi ini adalah makin pudarnya batas geografis di muka bumi. Informasi terbuka lebar bagi siapa saja yang ingin mengakses dan berkontribusi di dalamnya. Untuk melindungi hak-hak dan kewajiban baik penyedia informasi maupun pencari informasi dari kejahatan dunia maya (cyber crime), pemerintah telah menyusun beberapa perangkat perundangan. Pada tulisan ini akan dibahas mengenai peraturan perundangan tentang keterbukaan informasi publik (KIP) yang melindungi hak-hak masyarakat atas akses terhadap informasi yang dimiliki oleh instansi badan-badan publik. Contoh yang diberikan dikaitkan dengan penyediaan informasi bagi permasalahan lingkungan khususnya teknologi pengelolaan air bersih dan limbah cair yang telah dikelola oleh Pusat Teknologi Lingkungan, Badan Pengkajian Dan Penerapan Teknologi.

Since the Internet was introduced virtual network, the globalization of information gradually changes. One positive result of the globalization of this information is the geographical boundaries are not visible in the face of the earth. Information wide open to anyone who would like to access and contribute in it. To protect the rights and obligations of both the information providers and the users from the cyber crime, the government has prepared several law and legislation. On this paper, the regulation of public information opennes (Law Number 14/2008) will be discussed, which protect the rights of people to access information held by public agencies and institutions. Example given is associated with the provision of information for environmental problems, particularly water management technology and liquid waste that has been managed by the Center for Environmental Technology, Agency for the Assessment and Application of Technology. 